Article

\title{
Organic Contaminant Biodegradation by Oxidoreductase Enzymes in Wastewater Treatment
}

\author{
Edward A. Barber, Ziyi Liu and Stephen R. Smith * \\ Department of Civil and Environmental Engineering, Imperial College London, South Kensington Campus, \\ London SW7 2AZ, UK; edward.barber18@imperial.ac.uk (E.A.B.); ziyi.liu15@imperial.ac.uk (Z.L.) \\ * Correspondence: s.r.smith@imperial.ac.uk
}

Received: 15 November 2019; Accepted: 14 January 2020; Published: 16 January 2020

\begin{abstract}
Organic contaminants (OCs), such as pharmaceuticals, personal care products, flame retardants, and plasticisers, are societally ubiquitous, environmentally hazardous, and structurally diverse chemical compounds whose recalcitrance to conventional wastewater treatment necessitates the development of more effective remedial alternatives. The engineered application of ligninolytic oxidoreductase fungal enzymes, principally white-rot laccase, lignin peroxidase, and manganese peroxidase, has been identified as a particularly promising approach for OC remediation due to their strong oxidative power, broad substrate specificity, low energy consumption, environmental benignity, and cultivability from lignocellulosic waste. By applying an understanding of the mechanisms by which substrate properties influence enzyme activity, a set of semi-quantitative physicochemical criteria (redox potential, hydrophobicity, steric bulk and pKa) was formulated, against which the oxidoreductase degradation susceptibility of twenty-five representative OCs was assessed. Ionisable, compact, and electron donating group (EDG) rich pharmaceuticals and antibiotics were judged the most susceptible, whilst hydrophilic, bulky, and electron withdrawing group (EWG) rich polyhalogenated compounds were judged the least susceptible. OC susceptibility scores were in general agreement with the removal rates reported for experimental oxidoreductase treatments $\left(R^{2}=0.60\right)$. Based on this fundamental knowledge, and recent developments in enzyme immobilisation techniques, microbiological enzymic treatment strategies are proposed to formulate a new generation of biological wastewater treatment processes for the biodegradation of environmentally challenging OC compounds.
\end{abstract}

Keywords: organic contaminant; redox potential; oxidoreductase enzymes; enzymatic degradation

\section{Introduction}

Wastewater treatment plant (WWTP) effluents and biosolids are regularly found to contain a wide variety of heterogeneously structured novel micropollutants as chemically engineered production of anthropogenic compounds continues to diversify. Environmental organic contaminants (OCs) can be broadly characterised by their prevalence as ubiquitous necessities (e.g., antibiotics, pharmaceuticals, personal care products, hormones, plasticisers, flame retardants, surfactants, biocides, and preservatives), their recalcitrance to conventional wastewater treatment and natural degradation processes, their environmental persistence and bioaccumulation, their ubiquity at analytically challenging yet ecologically harmful ppb/ppt environmental concentrations, and their general lack of current source control legislation [1]. Importantly, whilst the environmental impacts of OC emission include endocrine disruption, food-web accumulation, ecological toxicity/mutagenicity/teratogenicity, and antibiotic resistance dissemination, the continuous discharge of OCs in wastewater effluent allows for even the least persistent OCs to potentially impart some degree of ecological harm upon receiving 
waters [2]. Thus, the development of effective, systematic, and economically and environmentally sustainable techniques that facilitate OC removal within the confines of WWTPs is urgently needed.

Recently, the application of isolated enzymes has gathered particularly significant attention for OC degradation [3]. Enzymatic treatment can have higher specificity for very low concentration and highly recalcitrant OCs and it produces less harmful by-products as compared to other physicochemical technologies, such as dense membrane filtration, advanced oxidation, and granular activated carbon adsorption [4,5]. Fungi oxidoreductase enzymes, including white-rot laccase, lignin peroxidase $(\mathrm{LiP})$, and manganese peroxidase $(\mathrm{MnP})$, which are synergistically employed to oxidatively and non-selectively cleave the resilient polyphenol structures of lignin during the decomposition of wood, distinguish themselves as promising candidates to remove OCs. For example, Alharbi et al. found that $5 \mathrm{mg} / \mathrm{L}$ of diclofenac, trimethoprim, carbamazepine, and sulfamethoxazole can be effectively degraded by laccase from Trametes versicolor, with the efficiency reaching $100 \%, 95 \%, 85 \%$, and $56 \%$, respectively [6]. Singh et al. reported that up to $75 \%$ of another OC, triclosan $(1.5-0.375 \mathrm{mg} / \mathrm{L})$, can be degraded by the free laccase produced from the same species of bacteria [7]. Similarly, Lip and MnP were also reported to be capable of degrading various phenolic and/or nonphenolic compounds under certain conditions [8-11].

The reaction of these oxidoreductase enzymes follows a radical reaction mechanism, driven by the redox potential differential between the enzyme active site and substrate. Laccase catalysis, for example, is initialised by a cycle of four single outer-sphere electron transfers between four phenolic substrate molecules, being sequentially bound at the primary electron accepting active site (with redox potential at $0.43-0.78 \mathrm{~V} \mathrm{[12]),} \mathrm{which} \mathrm{results} \mathrm{in} \mathrm{substrate} \mathrm{oxidation} \mathrm{and} \mathrm{the} \mathrm{generation} \mathrm{of} \mathrm{polymerisation} \mathrm{prone}$ phenoxy free radicals. Phenolic and aromatic compounds, which usually show relatively low redox potential, can be non-specifically decomposed by laccase, Lip, and MnP. Moreover, these enzymes also have ability to expand their specificity towards other non-phenolic and non-aromatic substrates (with redox potentials of up to $1.5 \mathrm{~V}$ under certain circumstances $[13,14])$.

However, future deployment of enzymatic treatment of OCs is strongly dependent on the ability to rapidly screen enzymes possessing specificity to the contaminants of concern [15]. This in itself must be founded upon an improved understanding of the factors controlling the susceptibility of a compound to enzymatic catalysis.

Currently, no established and rational technique exists, by which the susceptibility of OCs to enzymatic degradation can be systematically predicted, a fact that restricts the rationalisation of oxidoreductase treatment process design. This study aimed to construct a framework for assessing the susceptibility of OCs to fungal enzyme degradation, founded upon an understanding of the interrelationships between the physicochemical properties of the contaminant, the catalytic mechanism of the enzyme, and the conditions of the environment, and then apply this to recommend key criteria to consider in the design of enzymic treatment systems for OC removal from wastewater.

\section{Materials and Methods}

\subsection{Shortlist of Target OCs for Assessment}

Twenty-five representative contaminants (Table 1) were shortlisted to undergo detailed enzymatic susceptibility assessment. Each compound was selected due to it possessing a combination of a high detection frequency in wastewater/biosolids, a low average wastewater removal percentage relative to other compounds of the same subgroup, and a degree of environmental persistence, bioaccumulation and/or toxicity. 
Table 1. Shortlisted chemicals and their abbreviations.

\begin{tabular}{cccc}
\hline Chemical & Abbreviation & Chemical & Abbreviation \\
\hline Sulfamethoxazole & SMX & Triclosan & TRC \\
Erythromycin & ERY & $3,3^{\prime}, 4,4^{\prime}, 5,5^{\prime}, 6,6^{\prime}$-decabromodiphenyl ether & BDE-209 \\
Tetracycline & TET & Pentabromoethylbenzene & PBEB \\
Ofloxacin & OFL & Tris(1,3-dichloroisopropyl) phosphate & TDCPP \\
Trimethoprim & TMP & Diethylhexyl phthalate & DEHP \\
Diclofenac & DCF & 2-Hydroxybenzothiazole & OBT \\
Carbamazepine & CBZ & Tributyltin & TBT \\
Metoprolol & MTP & Perfluorooctanoic acid & PFOA \\
Gemfibrozil & GMF & Perfluorooctanesulfonic acid & PFOS \\
Benzophenone-3 & BZP & Tetrachlorodibenzo-p-dioxin & TCDD \\
Fluoxetine & FLX & 2,3,6,7-Pentachloronaphthalene & $2,3,6,7-P C N$ \\
Oestrone & OST & 2,3,4,6,7,8-Hexachlorodecane & CP-10 \\
Galaxolide & GLX & & \\
\hline
\end{tabular}

\subsection{Criterion Selection and Its Rationale}

Four physicochemical properties of contaminants that affect their suitability as fungal enzyme substrates are considered as criteria for the assessment process and are described, as follows.

- Criterion 1 (C1): Net electron donating group density

As the one-electron oxidation reactions oxidoreductases employ initialise substrate transformation are driven by the redox potential differential $(\Delta \mathrm{E})$ between the enzyme and its substrate, substrate molecules with lower redox potentials, weaker electron affinities, and, thus, greater electron transfer tendencies will be more susceptible to enzymatic oxidation, and subsequent transformation/removal [16]. Unfortunately, the structural density of electron donating groups (EDG) and electron withdrawing groups (EWG) was adopted as a proxy for redox potential, as the availability of redox potential data for the shortlisted contaminants is extremely limited. Here, the term: Net Electron Donating Group Density, represents the presence, balance, and strength of donating and withdrawing groups within a given contaminant.

- Criterion 2 (C2): Hydrophobicity

Hydrophobicity represents the tendency of a compound to partition and sorb from the aqueous phase into the nonaqueous phase [17]. Hydrophobicity is known to heavily impact upon the removal rates that were observed in wastewater treatment processes $[18,19]$ and also upon the susceptibility of contaminants to purified enzyme degradation [20,21].

- Criterion 3 (C3): Steric hindrance

For substrates only containing small substituents $\left(-\mathrm{OH},-\mathrm{CH}_{3},-\mathrm{OCH}_{3}, \mathrm{C}_{2} \mathrm{H}_{5}\right.$, etc.), electron donating/withdrawing strength dominates enzyme activity determination. However, for compounds possessing longer chained substituents, the enzyme-substrate (E-S) complex formation at the active site might be severely interfered via steric hindrance effects [22,23].

- Criterion 4 (C4): pKa

Some studies $[24,25]$ showed that compounds with lower pKa values display faster oxidation rates under physiological $\mathrm{pH}$ conditions and micropollutants can be more readily degraded by oxidoreductase at a $\mathrm{pH}$ that is higher than its $\mathrm{pKa}$.

\subsection{Criteria Weighting}

The weightings of the criteria were determined by considering the relative ability of each criterion to influence the enzymatic oxidation rate of the target OCs. Based on the supporting literature available, the relative importance ranking of each criterion was listed as: 
(1) Net electron donating group density [16,21,23,26-28];

(2) Hydrophobicity [20,21] and Steric Hindrance [22,23]; and,

(3) pKa $[24,25]$.

As such, the criteria weightings were set to 9-3-3-1 for net electron donating group density, hydrophobicity, steric hindrance, and pKa, respectively.

\subsection{Scoring for Each Criteria}

\subsubsection{Criterion 1: Net Electron Donating Group Density}

To produce a value of $\mathrm{C} 1$, the following methodology was adopted:

- Firstly, each donating and withdrawing substituent within the molecular structure of the shortlisted contaminants was identified and then assigned a score of 3,2, or 1, relative to its classification as a strong, medium, or weak group, respectively (Table 2).

- The donating and withdrawing group scores of each contaminant were separately tallied and the difference between these summations calculated.

- This difference was then divided by the contaminants molecular weight before being multiplied by 100 to provide a final normalised density-based parameter with units of net donating group score per $100 \mathrm{~g} / \mathrm{mol}$.

Overall, the contaminants with a final net electron donating group density value $>1$ (strong donating group dominance), $0-1$ (slight/moderate donating group dominance), or $<0$ (withdrawing group dominance) were assigned a susceptibility score of 9, 6, or 3, respectively. Contaminants only containing withdrawing groups were assigned a score of 0 . However, it must be clarified that, as donating and withdrawing substituents influence redox potential via electron density modification of the aromatic moiety to which they are attached, only the redox potential of aromatic compounds is influenced by their presence. The functional groups that are attached to aliphatic molecules are, therefore, considered to have no positive impact on oxidoreductase susceptibility in this criterion category and, as such, aliphatic contaminants were assigned a net electron donating group density susceptibility score of 0 .

\subsubsection{Criterion 2: Hydrophobicity}

Hydrophobicity of a substance is quantified by the log octanol-water partition coefficient (Log $\mathrm{K}_{\mathrm{ow}}$ ). The hydrophobic nature of a compound can be broadly classified, as follows: $\log \mathrm{K}_{\mathrm{ow}}<2.5=$ low hydrophobicity, $\log \mathrm{K}_{\mathrm{ow}} 2.5-4=$ moderate hydrophobicity, and $\log \mathrm{K}_{\mathrm{ow}}>4=$ high hydrophobicity [29]. As such, shortlisted contaminants possessing high, moderate, and low $\log \mathrm{K}_{\mathrm{ow}}$ values were assigned susceptibility scores of 3,2, and 1, respectively. 
Table 2. Electron donating/withdrawing strength and steric bulk of shortlisted organic contaminant (OC) substituents.

\begin{tabular}{|c|c|c|}
\hline Substituent & $\begin{array}{l}\text { Electron Donating/Withdrawing } \\
\text { Strength }{ }^{1}\end{array}$ & Steric Bulk ${ }^{2}$ \\
\hline \multicolumn{3}{|c|}{ Electron Donating Groups } \\
\hline -OH (hydroxyl) & Strong & Low \\
\hline$-\mathrm{R}($ Alkyl) & Medium & Medium $(<3 C)$, high $(\geq 3 C) *$ \\
\hline$-\mathrm{NH}_{2},-\mathrm{NHR},-\mathrm{NR}_{2}$ (amine) & Strong & Medium \\
\hline -ROR (ether) & Medium & Low \\
\hline$-\mathrm{SCH}_{3}$ & Weak & Low \\
\hline \multicolumn{3}{|c|}{ Electron Withdrawing Groups } \\
\hline$-\mathrm{COOH}$ (carboxyl) & Medium & Medium \\
\hline$-\mathrm{C}_{6} \mathrm{H}_{5}$ (phenyl) & Weak & High \\
\hline$-\mathrm{F},-\mathrm{Br},-\mathrm{Cl}$ (Halogen) & Medium & Low \\
\hline$-\mathrm{CONH}_{2},-\mathrm{CONHR},-\mathrm{CONR}_{2}$ (amide) & Strong & Medium \\
\hline -COOR (ester) & Medium & Medium \\
\hline -COR (acyl) & Medium & Medium \\
\hline$-\mathrm{SO}_{2} \mathrm{OH}$ & Medium & Unknown \\
\hline$-\mathrm{SO}_{2} \mathrm{NHR}$ & Strong & Unknown \\
\hline
\end{tabular}

${ }^{1}$ source: [30]; ${ }^{2}$ source: [31,32]; ${ }^{*}$ refers to the number of carbon of the substituent.

\subsubsection{Criterion 3: Steric Bulk}

The steric bulk of a substituent is numerically represented by its A-value. Highly, moderately, and minimally bulky substituents were defined as those with A-values $>3$, between $3-1$ and $<1$, respectively (Table 2). Contaminants with high, medium, and low steric bulks were, respectively, assigned susceptibility scores of 1,2 , and 3, respectively.

\subsubsection{Criterion 4: $\mathrm{pKa}$}

Shortlisted contaminants possessing pKa values that were above and below the typical $\mathrm{pH}$ of wastewater ( $\mathrm{pH}$ 7.5) were assigned susceptibility scores of -1 and 1 , respectively. The score of contaminants that was devoid of ionisable functional groups was left unchanged.

\subsection{Data Collection and Analysis}

For assessing the susceptibility of the OCs, Appendix A (Table A1) presents the detailed breakdown of EDG/EWG content, $\log \mathrm{K}_{\mathrm{ow}}$, steric bulk, and pKa data used to derive susceptibility scores for each shortlisted contaminant. Relevance analysis was carried out by statistical linear regression.

\section{Results and Discussion}

\subsection{Susceptibility Assessment Results}

Figure 1 presents the shortlisted contaminants in order of their assessed susceptibility to oxidoreductase degradation within a wastewater treatment context. The higher the total susceptibility score, the greater the predicted susceptibility to oxidoreductase degradation. 


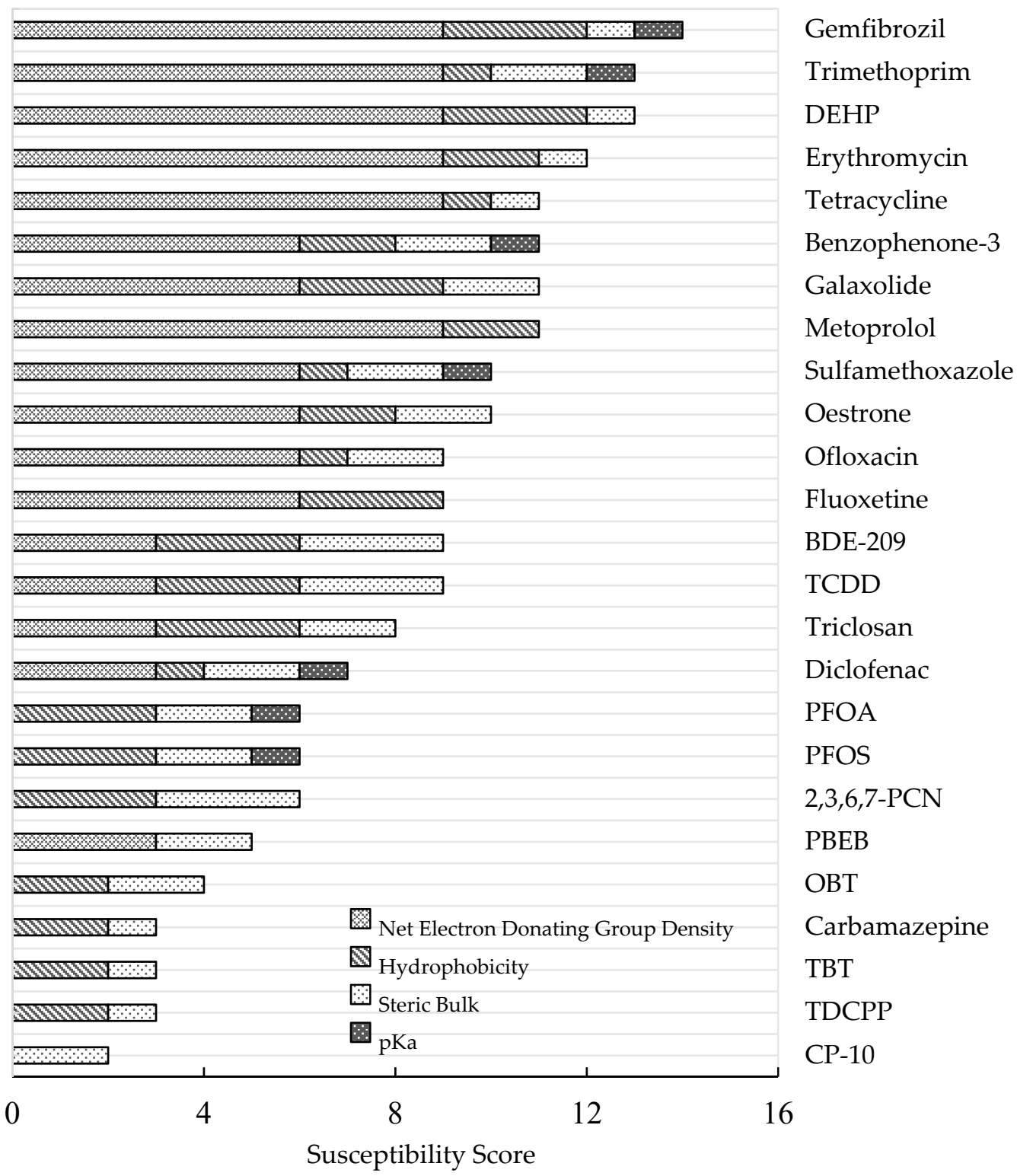

Figure 1. Shortlisted OCs in order of their assessed susceptibility to oxidoreductase degradation. The breakdown of individual criteria scores is represented by patterned bars.

From a possible total susceptibility score of 16 , Gemfibrozil, a lipid regulating pharmaceutical, scored the highest (14/16), whilst CP-10, which is a short-chained halogenated paraffin/polychlorinated naphthalene, scored the lowest (2/16). The ten most susceptible contaminants comprised four non-halogenated antibiotics (trimethoprim, erythromycin, tetracycline, and sulfamethoxazole), five non-halogenated pharmaceuticals/personal care products (gemfibrozil, metoprolol, benzophenone-3, galaxolide, and oestrone), and one non-halogenated plasticiser (DEHP). Conversely, the fifteen least susceptible contaminants comprised two halogenated surfactants (PFOA, PFOS), four halogenated flame retardants (PBEB, TDCPP, BDE-209, and 2,3,6,7-PCN), one halogenated plasticiser (CP-10), one halogenated antibiotic (ofloxacin), three pharmaceuticals (carbamazepine, diclofenac and fluoxetine), three biocides (OBT, TBT, triclosan), and one combustion by-product (TCDD).

Overall, the halogenated contaminants possessed, on average, a $32 \%$ lower susceptibility score (6.6/16) than non-halogenated compounds (9.7/16). This is consistent with the fact that the halogen (-X) groups are electron withdrawing groups; if not balanced with other electron donating groups within the molecule, they tend to increase the redox potential and electrophilicity of a compound by 
withdrawing electron density away from the aromatic ring [16]. The resulting electron sufficiency of the aromatic moiety decreases the compounds' susceptibility to oxidative catabolism.

\subsection{Comparison between the Susceptibility Scores of OCs and Their Removal by Oxidoreductase Treatment}

The results of the susceptibility assessment were compared with the published studies of the removal rates that were attained by various oxidoreductase treatment strategies (Figure 2). Linear regression analysis of the relationship showed that the degradation potential of a diverse range of OCs showed good agreement with the susceptibility scores for the compounds and gave an $R^{2}=0.60$ ( $p$ value $=0.002)$, providing confidence in the assessment framework to predict the susceptibility of OCs to oxidoreductase degradation.

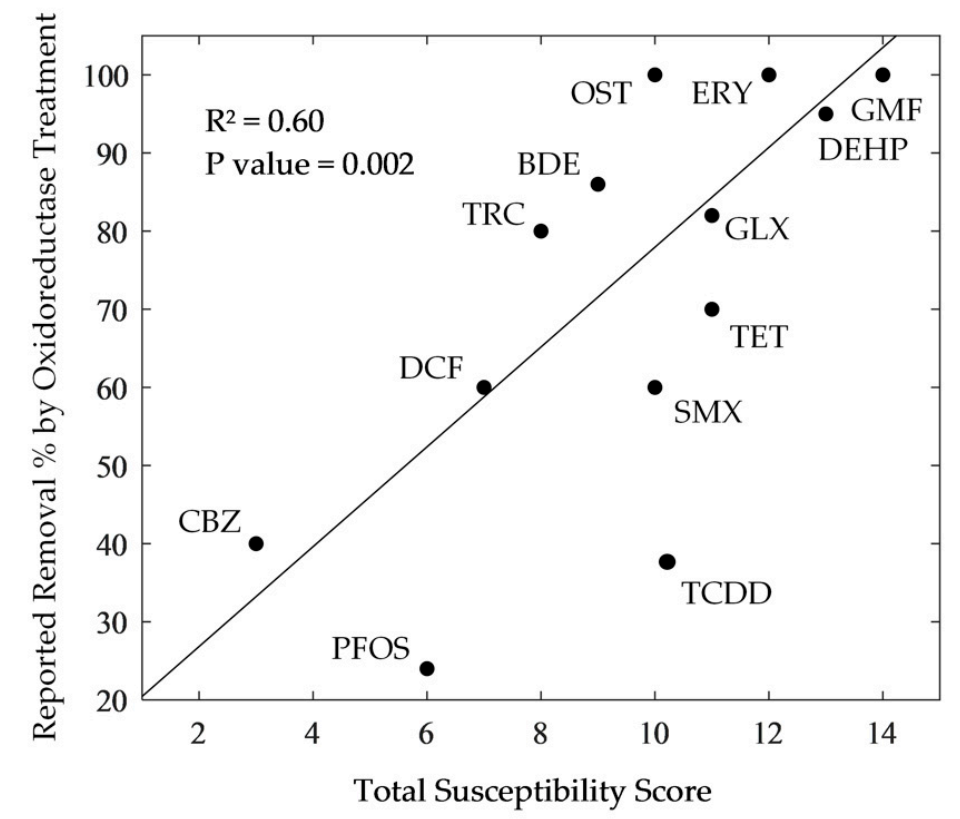

Figure 2. Correlation between total OC susceptibility scores and reported oxidoreductase treatment strategy removal rates (abbreviations were defined in Table 1).

Carbamazepine received a relatively low susceptibility score (3/16) due to its moderate hydrophobicity, high $\mathrm{pKa}$, moderate steric bulk, and lack of EDGs, which is strongly supported by reports of enzymatic recalcitrance. A GAC-immobilised Aspergillus oryzae laccase, for example, was reported to achieve $40 \%$ carbamazepine removal when compared to $60 \%, 60 \%$, and $98 \%$ for diclofenac (7/16), sulfamethoxazole (10/16), and bisphenol-A, respectively [4]. Similarly, whilst carbamazepine was reported to be negligibly removed by crude laccase (5-37\%), LiP (<10\%) and MnP (14-20\%), oestrone (10/16) showed much greater degradability under the same treatment conditions $(70-100 \%$, $60 \%$, and 99\%) [33]. Furthermore, Tinea versicolor laccase has been reported to achieve $82 \%$ removal of Galaxolide (11/16) [34] and 100\% removal of gemfibrozil (14/16) [35], whilst tetracycline (11/16) has been reported to undergo $70 \%$ and $72 \%$ removal by magnetically crosslinked Cerrena laccase [36] and crude MnP [3], respectively. Moreover, Ganoderma lucidum laccase, after one day of incubation, was able to degrade 95\% of DEHP (13/16) [37], whilst Pleurotus ostreatus laccase, after 36 days of incubation, could only degrade $24 \%$ of PFOA (6/16) [38]. Finally, removal efficiencies of $43 \%$ for carbamazepine (3/16), 64\% for diclofenac (7/16), 86\% for BDE-209 (9/16), 100\% for sulfamethoxazole (10/16), 100\% for oestrone (10/16), 100\% for benzophenone-3 (11/16), and 100\% for erythromycin (12/16) have been reported for the whole-cell T. versicolor treatment of thermally dried sewage sludge [39].

However, for certain shortlisted contaminants, susceptibility scores and experimental removal reports did not always fully agree. The oxidoreductase degradation of triclosan, in particular, is more efficient (70-90\%) than is expected from its susceptibility score (8/16) [40]. Triclosan is, 
however, the only shortlisted OC to bear a combination of halogen and phenolic substituents and, as such, the poor association between susceptibility score and the removal rate could arise from the idiosyncratic suppression of halogenic electron withdrawing effects by the donating and polymerisation inducing phenolic substituent [41]. More generally, such inconsistencies might be explained by the non-incorporation of additional known (e.g., reorganisation energy [42]) and ionisation potential [3] and unknown susceptibility criteria.

Furthermore, low susceptibility OCs, such as carbamazepine (3/16), PFOS (6/16), PFOA (6/16), Triclosan (8/16), BDE-209 (9/16), and TCDD (9/16) can still be degraded by the oxidoreductase enzymes under certain conditions, since the enzymes have the ability to expand their specificity towards low susceptibility OCs (e.g., non-phenolic and non-aromatic substrates). Many researchers have reported that the degradation of lower scoring OCs is more strongly predicated in the presence of redox mediators and other complimentary chemical constituents. With the addition of the "redox mediators", i.e., small diffusible redox-active phenolic co-substrates, such as 2,2'-azinobis(3-ethylbenzthiazoline-6-sulfonate) (ABTS) [43], 1-hydroxy-benzotriazole (HBT) [38,44], and p-coumaric acid (PCA) [45], free radicals generated from the oxidation of these redox mediators can non-specifically shuttle electrons towards, and abiotically oxidise, nearby non-phenolic molecules [21].

\subsection{Susceptibility Assessment Derived Design Recommendations}

\subsubsection{Enzyme Reactors and Enzyme Stabilisation}

Oxidoreductase enzymes have been applied experimentally within a wide array of engineered systems. Different types of enzymatic reactor have been reported, including: aqueous-phase orientated batch or continuous stirred tank, packed bed, fluidised bed, suspended nanoparticle, hollow fibre microfilter and hybrid membrane-nanoparticle suspension bioreactor systems, as well as solid-phase centric bioslurry and biopile technologies $[33,39,46]$. However, high rates of $\mathrm{pH} /$ thermal enzyme denaturation and low rates of enzyme retention, recovery, and reusability challenge the contaminant removal efficiency and the economic feasibility of enzymatic wastewater treatment [47]. Therefore, the stabilisation of the enzymes is necessary for practical implementation of enzymic treatment. Crucially, immobilisation facilitates the combinatory aggregation or successive application of disparate enzymes, which, in turn, provides the versatility that is required to treat complex pollutant mixtures under fluctuating or poorly defined conditions, which is often the case in wastewater matrices [46]. Conventional immobilisation of enzymes onto solid-supports/carriers (e.g., mesoporous silica and organic gels) by physisorption, entrapment, or encapsulation is regularly reported to reduce enzyme washout from continuous processes, widen enzymatic temperature and $\mathrm{pH}$ stability ranges through intermolecular stabilising forces, increase substrate availability by consolidative adsorption, and provide protection from inhibitory molecules [48-50]. Recently, an alternative, carrier-free immobilisation technique has been developed to stabilise the enzymes by moderate, covalent bonding with a cross-linker. This immobilisation approach reduces the activity losses that are associated with the inaccessibility of enzymes situated deep within the pores of conventional solid-supports, and it has shown potential for producing enzymatic microreactors to remove organic contaminants from wastewater [51]. For example, Lai et al. prepared nanotubes with laccases that were cross-linked to the surface to remove azo dyes. It was found that a decolourisation rate of $74-96 \%$ was possible and $90 \%$ of the initial decolourisation rate of the reactor was maintained after 10 sequential batch reactions [52]. Similar results were reported in [53] while using enzymatic membrane reactors that were produced by cross-linking. Lassouane et al. [54] also found that crosslinking of laccases prior to a conventional entrapment method increased the immobilisation efficiency by $30 \%$, and that more than $99 \%$ of the contaminant, Bisphenol A, was removed from aqueous solution by cross-linked enzymes. 


\subsubsection{Optimisation of Enzymatic Treatment}

The susceptibility assessment results that are presented here provide a rationale towards establishing potential process design recommendations for the enzymatic treatment of OCs: the treatment performance might be optimised by selecting and manipulating enzymes and wastewater conditions to exploit the fundamental OC susceptibility relationships, as follows.

- Redox Potential: If the typical OC content of a given wastewater stream can be established, and the redox potential of these OCs approximated from EDG/EWG analysis, an enzyme, or redox mediator can be selected that delivers the redox potential that is required for oxidation. The treatment of polyhalogenated OCs in wastewater, for example, is more likely to require the application of lignin peroxidase (1.0-1.2 V) over laccase (0.3-0.8 V), or ABTS (0.68 V) over syringaldehyde $(0.51 \mathrm{~V})$ [55], when compared to a predominantly antibiotic/pharmaceutical contaminated influent.

- $\quad$ Steric Bulk/Hindrance: Apart from stabilising the enzymes, the immobilisation techniques were also reported to minimise the steric hindrance of E-S complex formation. PEG, for example, can be employed as a flexible spacer that tethers and non-directly spatially disseminates enzymes across some solid-supports [56]; employment of these flexibly spaced enzymes in a treatment process may orientate certain subunits of OCs towards the enzymes active site in a more favourable way.

- $\quad$ KKa: If enzymatic stability ranges allow, the treatment unit should be operated at a $\mathrm{pH}$ that maximises the deprotonation and radicalisation potential of contaminant substituents. For example, an antibiotic and pharmaceutical rich hospital wastewater effluent could be treated by a laccase reactor ( $\mathrm{pH}$ stability $2-10$ ) at $\mathrm{pH} \sim 9$ to ensure the deprotonation and enhanced susceptibility of sulfamethoxazole (pKa 5.81), trimethoprim (pKa 7.20), erythromycin (pKa 8.90), ofloxacin (pKa 7.65), diclofenac (pKa 4.20), gemfibrozil (pKa 4.70), and fluoxetine (pKa 8.70).

\section{Conclusions}

Twenty-five representative OCs were shortlisted for susceptibility assessment to degradation by lignin degrading fungal enzymes. The physicochemical properties that determine the ability of OCs to act as fungal oxidoreductase substrates, namely redox potential, hydrophobicity, steric bulk, and $\mathrm{pKa}$, were translated into semi-quantitative assessment criteria. The susceptibility scores suggested that oxidoreductase treatment systems are the most effective at degrading EDG-rich, hydrophobic, compact, and ionisable aromatic contaminants, e.g., oestrone, and least effective at degrading EWG-rich, hydrophilic, bulky, and non-ionisable aliphatic contaminants, e.g., PFOS.

The assessment framework successfully incorporated the major criteria that control the efficacy of oxidoreductase OC degradation relative to the reported oxidoreductase treatment removals $\left(R^{2}=0.60\right.$, $p$ value $=0.002$ ). Although susceptibility scores and oxidoreductase treatment removal rates largely agreed, the susceptibility of triclosan was underestimated. The accuracy of susceptibility scores may be improved by incorporating additional criteria, or by calibrating criteria weightings by experimentally determining the relative importance of each physicochemical property.

As far as we know, this study is the first to construct a theoretical framework for predicting contaminant susceptibility to oxidoreductase degradation. As such, it has demonstrated the potential for, and practical utility of, theoretically linking the fundamental characteristics of disparate molecules towards deriving a value that broadly signifies the degree to which they will interact. Reasonably, this concept could be adapted for assessing the susceptibility of the contaminants to other treatment processes e.g., advanced oxidation, etc. 
Overall, as novel contaminants continue to emerge, the swift and strategic design and deployment of targeted wastewater treatments will become increasingly necessary, this will be more effective if based on theoretical, fundamental assessment frameworks that are similar to that proposed here, to provide rapid and reliable estimations of compound susceptibility and process efficacy. Ultimately, frameworks that predict the performance of oxidoreductase systems could, if developed alongside systems for improving mass enzyme producibility and immobilisation, make the application of fungal enzymes for sustainable wastewater treatment feasible.

Author Contributions: S.R.S. was the academic supervisor, proposed the original conceptualization, critically directed the research as it progressed and completed the final review and editing of the manuscript; E.A.B. was the MSc student undertaking the research, who developed the approach, completed the validation and prepared the thesis on which the paper was based; Z.L. was cosupervisor, contributing to the technical development of the research and prepared the manuscript for submission. All authors have read and agreed to the published version of the manuscript.

Funding: This research was unfunded.

Conflicts of Interest: The authors declare no conflict of interest. 


\section{Appendix A}

Table A1. Representative OCs shortlisted for susceptibility assessment and their respective assessment criteria data.

\begin{tabular}{|c|c|c|c|c|c|c|c|c|c|}
\hline $\begin{array}{c}\text { Organic } \\
\text { Contaminant }\end{array}$ & $\begin{array}{l}\text { Chemical } \\
\text { Formula }\end{array}$ & Chemical Structure ${ }^{\epsilon}$ & $\begin{array}{c}\text { Molecular Weight } \\
\text { (g/mol) }\end{array}$ & EDG Score & EWG Score & $\begin{array}{l}\text { Net Electron Donating } \\
\text { Group Density }\end{array}$ & pKa & $\log K_{\text {ow }}$ & Steric Bulk \\
\hline Sulfamethoxazole & $\mathrm{C}_{10} \mathrm{H}_{11} \mathrm{~N}_{3} \mathrm{O}_{3} \mathrm{~S}$ & & 253.28 & 5 & 3 & 0.79 & $5.81^{1}$ & $0.89^{2}$ & Medium \\
\hline Erythromycin & $\mathrm{C}_{37} \mathrm{H}_{67} \mathrm{NO}_{13}$ & & 733.93 & 19 & 4 & 2.04 & $8.90^{3}$ & $3.10^{3}$ & Medium \\
\hline Tetracycline & $\mathrm{C}_{22} \mathrm{H}_{24} \mathrm{~N}_{2} \mathrm{O}_{8}$ & & 444.43 & 13 & 6 & 1.58 & $9.69^{4}$ & $-1.33^{5}$ & Medium \\
\hline Ofloxacin & $\mathrm{C}_{18} \mathrm{H}_{20} \mathrm{FN}_{3} \mathrm{O}_{4}$ & & 361.37 & 8 & 6 & 0.55 & $7.65^{6}$ & $0.00^{5}$ & Low \\
\hline
\end{tabular}


Table A1. Cont.

\begin{tabular}{|c|c|c|c|c|c|c|c|c|c|}
\hline $\begin{array}{c}\text { Organic } \\
\text { Contaminant }\end{array}$ & $\begin{array}{l}\text { Chemical } \\
\text { Formula }\end{array}$ & Chemical Structure $^{\epsilon}$ & $\begin{array}{c}\text { Molecular Weight } \\
(\mathrm{g} / \mathrm{mol})\end{array}$ & EDG Score & EWG Score & $\begin{array}{l}\text { Net Electron Donating } \\
\text { Group Density }\end{array}$ & pKa & $\log K_{\text {ow }}$ & Steric Bulk \\
\hline Trimethoprim & $\mathrm{C}_{14} \mathrm{H}_{18} \mathrm{~N}_{4} \mathrm{O}_{3}$ & & 290.32 & 12 & 0 & 4.13 & $7.20^{7}$ & $0.91^{2}$ & Medium \\
\hline Diclofenac & $\mathrm{C}_{14} \mathrm{H}_{11} \mathrm{Cl}_{2} \mathrm{NO}_{2}$ & & 296.15 & 3 & 6 & -1.01 & $4.20^{2}$ & $0.70^{2}$ & Medium \\
\hline Carbamazepine & $\mathrm{C}_{15} \mathrm{H}_{12} \mathrm{~N}_{2} \mathrm{O}$ & & 236.27 & 0 & 2 & -0.85 & $13.9^{8}$ & $2.25^{5}$ & Medium \\
\hline Metoprolol & $\mathrm{C}_{15} \mathrm{H}_{25} \mathrm{NO}_{3}$ & & 267.36 & 11 & 0 & 4.11 & $9.60^{2}$ & $2.15^{2}$ & High \\
\hline Gemfibrozil & $\mathrm{C}_{15} \mathrm{H}_{22} \mathrm{O}_{3}$ & & 250.33 & 8 & 2 & 2.40 & $4.70^{2}$ & $4.77^{2}$ & High \\
\hline Benzophenone-3 & $\mathrm{C}_{14} \mathrm{H}_{12} \mathrm{O}_{3}$ & & 228.24 & 5 & 3 & 0.88 & 7.10 & $3.79^{9}$ & Medium \\
\hline
\end{tabular}


Table A1. Cont.

\begin{tabular}{|c|c|c|c|c|c|c|c|c|c|}
\hline $\begin{array}{c}\text { Organic } \\
\text { Contaminant }\end{array}$ & $\begin{array}{l}\text { Chemical } \\
\text { Formula }\end{array}$ & Chemical Structure $^{\epsilon}$ & $\begin{array}{c}\text { Molecular Weight } \\
\text { (g/mol) }\end{array}$ & EDG Score & EWG Score & $\begin{array}{l}\text { Net Electron Donating } \\
\text { Group Density }\end{array}$ & pKa & $\log K_{\text {ow }}$ & Steric Bulk \\
\hline Fluoxetine & $\mathrm{C}_{17} \mathrm{H}_{18} \mathrm{~F}_{3} \mathrm{NO}$ & & 309.33 & 5 & 3 & 0.65 & $8.70^{10}$ & $4.05^{10}$ & High \\
\hline Oestrone & $\mathrm{C}_{18} \mathrm{H}_{22} \mathrm{O}_{2}$ & & 270.37 & 3 & 2 & 0.74 & $10.34^{2}$ & $3.13^{2}$ & Low \\
\hline Galaxolide & $\mathrm{C}_{18} \mathrm{H}_{26} \mathrm{O}$ & & 258.40 & 12 & 0 & 4.64 & l & $5.90^{11}$ & Medium \\
\hline Triclosan & $\mathrm{C}_{12} \mathrm{H}_{7} \mathrm{Cl}_{3} \mathrm{O}_{2}$ & & 289.54 & 5 & 6 & -0.35 & $7.80^{10}$ & $4.76^{10}$ & Low \\
\hline
\end{tabular}


Table A1. Cont.

\begin{tabular}{|c|c|c|c|c|c|c|c|c|c|}
\hline $\begin{array}{c}\text { Organic } \\
\text { Contaminant }\end{array}$ & $\begin{array}{l}\text { Chemical } \\
\text { Formula }\end{array}$ & Chemical Structure ${ }^{\epsilon}$ & $\begin{array}{c}\text { Molecular Weight } \\
(\mathrm{g} / \mathrm{mol})\end{array}$ & EDG Score & EWG Score & $\begin{array}{l}\text { Net Electron Donating } \\
\text { Group Density }\end{array}$ & pKa & $\log K_{\text {ow }}$ & Steric Bulk \\
\hline BDE-209 & $\mathrm{C}_{12} \mathrm{Br}_{10} \mathrm{O}$ & & 959.17 & 2 & 20 & -1.88 & l & $12.11^{12}$ & Low \\
\hline РBEB & $\mathrm{C}_{8} \mathrm{H}_{5} \mathrm{Br}_{5}$ & & 500.65 & 2 & 10 & -1.60 & l & l & Medium \\
\hline TDCPP & $\mathrm{C}_{9} \mathrm{H}_{15} \mathrm{Cl}_{6} \mathrm{O}_{4} \mathrm{P}$ & & 430.90 & l & l & l & l & $3.76^{9}$ & High \\
\hline DEHP & $\mathrm{C}_{24} \mathrm{H}_{38} \mathrm{O}_{4}$ & & 390.56 & 8 & 4 & 1.02 & l & $7.60^{12}$ & High \\
\hline OBT & $\mathrm{C}_{7} \mathrm{H}_{5} \mathrm{NOS}$ & & 151.19 & 0 & 2 & -1.32 & l & $1.76^{11}$ & Medium \\
\hline TBT & $\mathrm{C}_{12} \mathrm{H}_{27} \mathrm{Sn}$ & & 290.05 & I & 1 & 1 & I & $3.52^{11}$ & High \\
\hline
\end{tabular}


Table A1. Cont.

\begin{tabular}{|c|c|c|c|c|c|c|c|c|c|}
\hline $\begin{array}{c}\text { Organic } \\
\text { Contaminant }\end{array}$ & $\begin{array}{l}\text { Chemical } \\
\text { Formula }\end{array}$ & Chemical Structure ${ }^{\epsilon}$ & $\begin{array}{l}\text { Molecular Weight } \\
\text { (g/mol) }\end{array}$ & EDG Score & EWG Score & $\begin{array}{l}\text { Net Electron Donating } \\
\text { Group Density }\end{array}$ & pKa & $\log K_{\text {ow }}$ & Steric Bulk \\
\hline PFOA & $\mathrm{C}_{8} \mathrm{HF}_{15} \mathrm{O}_{2}$ & & 414.07 & 1 & I & 1 & $1.30^{13}$ & $4.81^{9}$ & Medium \\
\hline PFOS & $\mathrm{C}_{8} \mathrm{~F}_{17} \mathrm{O}_{3} \mathrm{~S}$ & & 499.12 & 1 & 1 & 1 & $-3.3^{9}$ & $4.49^{9}$ & Medium \\
\hline TCDD & $\mathrm{C}_{12} \mathrm{H}_{4} \mathrm{Cl}_{4} \mathrm{O}_{2}$ & & 321.97 & 4 & 8 & -1.24 & 1 & $6.80^{9}$ & Low \\
\hline 2,3,6,7-PCN & $\mathrm{C}_{10} \mathrm{H}_{4} \mathrm{Cl}_{4}$ & & 265.95 & 0 & 8 & -3.01 & 1 & $6.19^{9}$ & Low \\
\hline CP-10 & $\mathrm{C}_{10} \mathrm{H}_{16} \mathrm{Cl}_{6}$ & & 348.98 & 1 & 1 & 1 & 1 & I & Medium \\
\hline
\end{tabular}

${ }^{1}$ source: [57], ${ }^{2}$ source: [58], ${ }^{3}$ source: [59], ${ }^{4}$ source: [60], ${ }^{5}$ source: [61], ${ }^{6}$ source: [62], ${ }^{7}$ source: [63] ${ }^{8}$ source: [29], ${ }^{9}$ source: [64], ${ }^{10}$ source: [65], ${ }^{11}$ source: [66], ${ }^{12}$ source: [67], ${ }^{13}$ source: [68]. Legend:

Electron withdrawing groups




\section{References}

1. Tran, N.H.; Reinhard, M.; Gin, K.Y.H. Occurrence and fate of emerging contaminants in municipal wastewater treatment plants from different geographical regions-a review. Water Res. 2018, 133, 182-207. [CrossRef]

2. Petrovic, M.; Gonzalez, S.; Barcelo, D. Analysis and removal of emerging contaminants in wastewater and drinking water. TrAC Trends Anal. Chem. 2003, 22, 685-696. [CrossRef]

3. Mendez, E.; Gonzalez-Fuentes, M.A.; Rebollar-Perez, G.; Mendez-Albores, A.; Torres, E. Emerging pollutant treatments in wastewater: Cases of antibiotics and hormones. J. Environ. Sci. Health Part A 2017, 52, 235-253. [CrossRef]

4. Alshabib, M.; Onaizi, S.A. A review on phenolic wastewater remediation using homogeneous and heterogeneous enzymatic processes: Current status and potential challenges. Sep. Purif. Technol. 2019, 219, 186-207. [CrossRef]

5. Haugland, J.O.; Kinney, K.A.; Johnson, W.H.; Camino, M.M.A.; Whitman, C.P.; Lawler, D.F. Laccase removal of 2-chlorophenol and sulfamethoxazole in municipal wastewater. Water Environ. Res. 2019, 91, 281-291. [CrossRef] [PubMed]

6. $\quad$ Alharbi, S.K.; Nghiem, L.D.; van de Merwe, J.P.; Leusch, F.D.L.; Asif, M.B.; Hai, F.I.; Price, W.E. Degradation of diclofenac, trimethoprim, carbamazepine, and sulfamethoxazole by laccase from Trametes versicolor: Transformation products and toxicity of treated effluent. Biocatal. Biotransform. 2019, 37, 399-408. [CrossRef]

7. Singh, J.; Kumar, P.; Saharan, V.; Kapoor, R.K. Simultaneous laccase production and transformation of bisphenol-A and triclosan using Trametes versicolor. 3 Biotech 2019, 9, 16. [CrossRef] [PubMed]

8. Ward, G.; Belinky, P.A.; Hadar, Y.; Bilkis, I.; Dosoretz, C.G. The influence of non-phenolic mediators and phenolic co-substrates on the oxidation of 4-bromophenol by lignin peroxidase. Enzym. Microb. Technol. 2002, 30, 490-498. [CrossRef]

9. Sayadi, S.; Ellouz, R. Roles of lignin peroxidase and manganese peroxidase from Phanerochaete chrysosporium in the decolorization of olive mill wastewaters. Appl. Environ. Microbiol. 1995, 61, 1098-1103. [CrossRef]

10. Acevedo, F.; Pizzul, L.; Castillo, M.D.; Gonzalez, M.E.; Cea, M.; Gianfreda, L.; Diez, M.C. Degradation of polycyclic aromatic hydrocarbons by free and nanoclay-immobilized manganese peroxidase from Anthracophyllum discolor. Chemosphere 2010, 80, 271-278. [CrossRef]

11. Baborova, P.; Moder, M.; Baldrian, P.; Cajthamlova, K.; Cajthaml, T. Purification of a new manganese peroxidase of the white-rot fungus Irpex lacteus, and degradation of polycyclic aromatic hydrocarbons by the enzyme. Res. Microbiol. 2006, 157, 248-253. [CrossRef] [PubMed]

12. Morozova, O.V.; Shumakovich, G.P.; Shleev, S.V.; Yaropolov, Y.I. Laccase-mediator systems and their applications: A review. Appl. Biochem. Microbiol. 2007, 43, 523-535. [CrossRef]

13. Hilgers, R.; Vincken, J.P.; Gruppen, H.; Kabel, M.A. Laccase/mediator systems: Their reactivity toward phenolic lignin structures. ACS Sustain. Chem. Eng. 2018, 6, 2037-2046. [CrossRef] [PubMed]

14. Pulicharla, R.; Das, R.K.; Brar, S.K.; Drogui, P.; Surampalli, R.Y. Degradation kinetics of chlortetracycline in wastewater using ultrasonication assisted laccase. Chem. Eng. J. 2018, 347, 828-835. [CrossRef]

15. Stadlmair, L.F.; Letzel, T.; Drewes, J.E.; Grassmann, J. Enzymes in removal of pharmaceuticals from wastewater: A critical review of challenges, applications and screening methods for their selection. Chemosphere 2018, 205, 649-661. [CrossRef] [PubMed]

16. Margot, J.; Bennati-Granier, C.; Maillard, J.; Blanquez, P.; Barry, D.A.; Holliger, C. Bacterial versus fungal laccase: Potential for micropollutant degradation. AMB Express 2013, 3. [CrossRef]

17. Kaliszan, R. QSRR: Quantitative structure-(chromatographic) retention relationships. Chem. Rev. 2007, 107, 3212-3246. [CrossRef]

18. Pham, T.T.; Proulx, S. PCBs and PAHs in the Montreal Urban Community (Quebec, Canada) wastewater treatment plant and in the effluent plume in the St Lawrence River. Water Res. 1997, 31, 1887-1896. [CrossRef]

19. Grandclement, C.; Seyssiecq, I.; Piram, A.; Wong-Wah-Chung, P.; Vanot, G.; Tiliacos, N.; Roche, N.; Doumenq, P. From the conventional biological wastewater treatment to hybrid processes, the evaluation of organic micropollutant removal: A review. Water Res. 2017, 111, 297-317. [CrossRef]

20. Mehra, R.; Muschiol, J.; Meyer, A.S.; Kepp, K.P. A structural-chemical explanation of fungal laccase activity. Sci. Rep. 2018, 8, 17258. [CrossRef] 
21. Yang, S.; Hai, F.I.; Nghiem, L.D.; Price, W.E.; Roddick, F.; Moreira, M.T.; Magram, S.F. Understanding the factors controlling the removal of trace organic contaminants by white-rot fungi and their lignin modifying enzymes: A critical review. Bioresour. Technol. 2013, 141, 97-108. [CrossRef] [PubMed]

22. Tadesse, M.A.; D'Annibale, A.; Galli, C.; Gentili, P.; Sergi, F. An assessment of the relative contributions of redox and steric issues to laccase specificity towards putative substrates. Org. Biomol. Chem. 2008, 6, 868-878. [CrossRef] [PubMed]

23. $\mathrm{Xu}, \mathrm{F}$. Oxidation of phenols, anilines, and benzenethiols by fungal laccases: Correlation between activity and redox potentials as well as halide inhibition. Biochemistry 1996, 35, 7608-7614. [CrossRef] [PubMed]

24. Camarero, S.; Ibarra, D.; Martinez, M.J.; Martinez, A.T. Lignin-derived compounds as efficient laccase mediators for decolorization of different types of recalcitrant dyes. Appl. Environ. Microbiol. 2005, 71, 1775-1784. [CrossRef]

25. Ba, S.; Arsenault, A.; Hassani, T.; Jones, J.P.; Cabana, H. Laccase immobilization and insolubilization: From fundamentals to applications for the elimination of emerging contaminants in wastewater treatment. Crit. Rev. Biotechnol. 2013, 33, 404-418. [CrossRef]

26. Rodriguez-Delgado, M.; Orona-Navar, C.; Garcia-Morales, R.; Hernandez-Luna, C.; Parra, R.; Mahlknecht, J.; Ornelas-Soto, N. Biotransformation kinetics of pharmaceutical and industrial micropollutants in groundwaters by a laccase cocktail from Pycnoporus sanguineus CS43 fungi. Int. Biodeterior. Biodegrad. 2016, 108, 34-41. [CrossRef]

27. Tadkaew, N.; Hai, F.I.; McDonald, J.A.; Khan, S.J.; Nghiem, L.D. Removal of trace organics by MBR treatment: The role of molecular properties. Water Res. 2011, 45, 2439-2451. [CrossRef]

28. Wehaidy, H.R.; El-Hennawi, H.M.; Ahmed, S.A.; Abdel-Naby, M.A. Comparative study on crude and partially purified laccase from Polyporus durus ATCC 26726 in the decolorization of textile dyes and wastewater treatment. Egypt. Pharm. J. 2018, 17, 94-103. [CrossRef]

29. Jones, O.A.H.; Voulvoulis, N.; Lester, J.N. Human pharmaceuticals in wastewater treatment processes. Crit. Rev. Environ. Sci. Technol. 2005, 35, 401-427. [CrossRef]

30. Remya, G.S.; Suresh, C.H. Quantification and classification of substituent effects in organic chemistry: A theoretical molecular electrostatic potential study. Phys. Chem. Chem. Phys. 2016, 18, 20615-20626. [CrossRef]

31. Eliel, E.L.; Wilen, S.H.; Mander, L.N. Stereochemistry of Organic Compounds; Wiley-Blackwell: New York, NY, USA, 1994; ISBN 978-0471016700.

32. Hirsch, J.A. Topics in Stereochemistry, 1st ed.; John Wiley \& Sons Inc.: New York, NY, USA, 1967.

33. Asif, M.B.; Hai, F.I.; Singh, L.; Price, W.E.; Nghiem, L.D. Degradation of pharmaceuticals and personal care products by white-rot fungi-A critical review. Curr. Pollut. Rep. 2017, 3, 88-103. [CrossRef]

34. Vallecillos, L.; Sadef, Y.; Borrull, F.; Pocurull, E.; Bester, K. Degradation of synthetic fragrances by laccase-mediated system. J. Hazard. Mater. 2017, 334, 233-243. [CrossRef] [PubMed]

35. Vasiliadou, I.A.; Sanchez-Vazquez, R.; Molina, R.; Martinez, F.; Melero, J.A.; Bautista, L.F.; Iglesias, J.; Morales, G. Biological removal of pharmaceutical compounds using white-rot fungi with concomitant FAME production of the residual biomass. J. Environ. Manag. 2016, 180, 228-237. [CrossRef] [PubMed]

36. Yang, J.; Wang, Z.J.; Lin, Y.H.; Ng, T.B.; Ye, X.Y.; Lin, J. Immobilized Cerrena sp laccase: Preparation, thermal inactivation, and operational stability in malachite green decolorization. Sci. Rep. 2017, 7. [CrossRef]

37. Liao, C.S.; Yuan, S.Y.; Hung, B.H.; Chang, B.V. Removal of organic toxic chemicals using the spent mushroom compost of Ganoderma lucidum. J. Environ. Monit. 2012, 14, 1983-1988. [CrossRef]

38. Luo, Q.; Liang, S.T.; Huang, Q.G. Laccase induced degradation of perfluorooctanoic acid in a soil slurry. J. Hazard. Mater. 2018, 359, 241-247. [CrossRef]

39. Rodriguez-Rodriguez, C.E.; Baron, E.; Gago-Ferrero, P.; Jelic, A.; Llorca, M.; Farre, M.; Diaz-Cruz, M.S.; Eljarrat, E.; Petrovic, M.; Caminal, G.; et al. Removal of pharmaceuticals, polybrominated flame retardants and UV-filters from sludge by the fungus Trametes versicolor in bioslurry reactor. J. Hazard. Mater. 2012, 233, 235-243. [CrossRef]

40. Cajthaml, T.; Křesinová, Z.; Svobodová, K.; Möder, M. Biodegradation of endocrine-disrupting compounds and suppression of estrogenic activity by ligninolytic fungi. Chemosphere 2009, 75, 745-750. [CrossRef]

41. Dou, R.N.; Wang, J.H.; Chen, Y.C.; Hu, Y.Y. The transformation of triclosan by laccase: Effect of humic acid on the reaction kinetics, products and pathway. Environ. Pollut. 2018, 234, 88-95. [CrossRef] 
42. Mehra, R.; Kepp, K.P. Contribution of substrate reorganization energies of electron transfer to laccase activity. Phys. Chem. Chem. Phys. 2019, 21, 15805-15814. [CrossRef]

43. Chu, P.K.H. Purification and characterization of laccase involved in the decolourization of synthetic dyes and 2,3,7,8-TCDD congener degradation by the Wwhite rot fungus isolated from Bavi Forest of Vietnam. Vietnam J. Sci. Technol. 2017, 55, 180-185. [CrossRef]

44. Luo, Q.; Lu, J.H.; Zhang, H.; Wang, Z.Y.; Feng, M.B.; Chiang, S.Y.D.; Woodward, D.; Huang, Q.G. Laccase-catalyzed degradation of perfluorooctanoic acid. Environ. Sci. Technol. Lett. 2015, 2, 198-203. [CrossRef]

45. Ji, C.; Hou, J.W.; Wang, K.; Zhang, Y.T.; Chen, V. Biocatalytic degradation of carbamazepine with immobilized laccase-mediator membrane hybrid reactor. J. Membr. Sci. 2016, 502, 11-20. [CrossRef]

46. Kues, U. Fungal enzymes for environmental management. Curr. Opin. Biotechnol. 2015, 33, $268-278$. [CrossRef] [PubMed]

47. Li, N.; Xia, Q.Y.; Li, Y.; Hou, X.B.; Niu, M.H.; Ping, Q.W.; Xiao, H.N. Immobilizing laccase on modified cellulose/CF beads to degrade chlorinated biphenyl in wastewater. Polymers 2018, 10, 798. [CrossRef] [PubMed]

48. Basso, A.; Serban, S. Industrial applications of immobilized enzymes-A review. Mol. Catal. 2019, 479, 35-54. [CrossRef]

49. Mateo, C.; Palomo, J.M.; Fernandez-Lorente, G.; Guisan, J.M.; Fernandez-Lafuente, R. Improvement of enzyme activity, stability and selectivity via immobilization techniques. Enzym. Microb. Technol. 2007, 40, 1451-1463. [CrossRef]

50. Sheldon, R.A. Enzyme immobilization: The quest for optimum performance. Adv. Synth. Catal. 2007, 349, 1289-1307. [CrossRef]

51. Sheldon, R.A.; van Pelt, S. Enzyme immobilisation in biocatalysis: Why, what and how. Chem. Soc. Rev. 2013, 42, 6223-6235. [CrossRef]

52. Lai, Y.X.; Wang, F.; Zhang, Y.M.; Ou, P.; Wu, P.P.; Fang, Q.L.; Li, S.; Chen, Z. Effective removal of methylene blue and orange II by subsequent immobilized laccase decolorization on crosslinked polymethacrylate/carbon nanotubes. Mater. Res. Express 2019, 6, 085541. [CrossRef]

53. Veismoradi, A.; Mousavi, S.M.; Taherian, M. Decolorization of dye solutions by tyrosinase in enzymatic membrane reactors. J. Chem. Technol. Biotechnol. 2019, 94, 3559-3568. [CrossRef]

54. Lassouane, F.; Ait-Amar, H.; Amrani, S.; Rodriguez-Couto, S. A promising laccase immobilization approach for Bisphenol A removal from aqueous solutions. Bioresour. Technol. 2019, 271, 360-367. [CrossRef]

55. Frasconi, M.; Favero, G.; Boer, H.; Koivula, A.; Mazzei, F. Kinetic and biochemical properties of high and low redox potential laccases from fungal and plant origin. Biochim. Biophys. Acta Proteins Proteom. 2010, 1804, 899-908. [CrossRef]

56. Manta, C.; Ferraz, N.; Betancor, L.; Antunes, G.; Batista-Viera, F.; Carlsson, J.; Caldwell, K. Polyethylene glycol as a spacer for solid-phase enzyme immobilization. Enzym. Microb. Technol. 2003, 33, 890-898. [CrossRef]

57. Hanai, T.; Miyazaki, R.; Koseki, A.; Kinoshita, T. Computational chemical analysis of the retention of acidic drugs on a pentyl-bonded silica gel in reversed-phase liquid chromatography. J. Chromatogr. Sci. 2004, 42, 354-360. [CrossRef] [PubMed]

58. Behera, S.K.; Kim, H.W.; Oh, J.E.; Park, H.S. Occurrence and removal of antibiotics, hormones and several other pharmaceuticals in wastewater treatment plants of the largest industrial city of Korea. Sci. Total Environ. 2011, 409, 4351-4360. [CrossRef] [PubMed]

59. Tarpani, R.R.Z.; Azapagic, A. A methodology for estimating concentrations of pharmaceuticals and personal care products (PPCPs) in wastewater treatment plants and in freshwaters. Sci. Total Environ. 2018, 622, 1417-1430. [CrossRef] [PubMed]

60. Qiang, Z.; Adams, C. Potentiometric determination of acid dissociation constants (pKa) for human and veterinary antibiotics. Water Res. 2004, 38, 2874-2890. [CrossRef]

61. Sanderson, H.; Thomsen, M. Comparative analysis of pharmaceuticals versus industrial chemicals acute aquatic toxicity classification according to the United Nations classification system for chemicals. Assessment of the (Q) SAR predictability of pharmaceuticals acute aquatic toxicity and their predominant acute toxic mode-of-action. Toxicol. Lett. 2009, 187, 84-93. [CrossRef] 
62. Vieno, N.M.; Harkki, H.; Tuhkanen, T.; Kronberg, L. Occurrence of pharmaceuticals in river water and their elimination a pilot-scale drinking water treatment plant. Environ. Sci. Technol. 2007, 41, 5077-5084. [CrossRef]

63. Boxall, A.B.A.; Johnson, P.; Smith, E.J.; Sinclair, C.J.; Stutt, E.; Levy, L.S. Uptake of veterinary medicines from soils into plants. J. Agric. Food Chem. 2006, 54, 2288-2297. [CrossRef] [PubMed]

64. PubChem. Available online: https://pubchem.ncbi.nlm.nih.gov (accessed on 16 September 2004).

65. Kumar, R.; Sarmah, A.K.; Padhye, L.P. Fate of pharmaceuticals and personal care products in a wastewater treatment plant with parallel secondary wastewater treatment train. J. Environ. Manag. 2019, 233, 649-659. [CrossRef] [PubMed]

66. Clarke, B.O.; Smith, S.R. Review of 'emerging' organic contaminants in biosolids and assessment of international research priorities for the agricultural use of biosolids. Environ. Int. 2011, 37, 226-247. [CrossRef] [PubMed]

67. Sanchez-Avila, J.; Bonet, J.; Velasco, G.; Lacorte, S. Determination and occurrence of phthalates, alkylphenols, bisphenol A, PBDEs, PCBs and PAHs in an industrial sewage grid discharging to a Municipal Wastewater Treatment Plant. Sci. Total Environ. 2009, 407, 4157-4167. [CrossRef]

68. Kutsuna, S.; Hori, H. Experimental determination of Henry's law constant of perfluorooctanoic acid (PFOA) at 298K by means of an inert-gas stripping method with a helical plate. Atmos. Environ. 2008, 42, 8883-8892. [CrossRef]

(C) 2020 by the authors. Licensee MDPI, Basel, Switzerland. This article is an open access article distributed under the terms and conditions of the Creative Commons Attribution (CC BY) license (http://creativecommons.org/licenses/by/4.0/). 